\title{
Comparison of antioxidant activity between green and roasted coffee beans using molecular methods
}

\author{
ALEXANDROS PRIFTIS $^{1}$, DIMITRIOS STAGOS ${ }^{1}$, KONSTANTINOS KONSTANTINOPOULOS ${ }^{2}$, \\ CHRISTINA TSITSIMPIKOU ${ }^{3}$, DEMETRIOS A. SPANDIDOS ${ }^{4}$, ARISTIDES M. TSATSAKIS ${ }^{5}$, \\ MANOLIS N. TZATZARAKIS ${ }^{5}$ and DEMETRIOS KOURETAS ${ }^{1}$ \\ ${ }^{1}$ Department of Biochemistry and Biotechnology, University of Thessaly, Larissa 41221; \\ ${ }^{2}$ Coffee Island S.A., Patras 26334; ${ }^{3}$ Department of Dangerous Substances, Mixtures and Articles, \\ Directorate of Environment, General Chemical State Laboratory of Greece, Athens 11521; ${ }^{4}$ Laboratory of Clinical Virology, \\ University of Crete, Medical School, Heraklion 71409; ${ }^{5}$ Department of Forensic Sciences \\ and Toxicology, Medical School, University of Crete, Heraklion 71003, Greece
}

Received August 25, 2015; Accepted September 28, 2015

DOI: $10.3892 / \mathrm{mmr} .2015 .4377$

\begin{abstract}
Coffee is one of the most popular and widely consumed beverages worldwide due to its pleasant taste and aroma. A number of studies have been performed to elucidate the possible beneficial effects of coffee consumption on human health and have shown that coffee exhibits potent antioxidant activity, which may be attributed mainly to its polyphenolic content. However, there is also evidence to suggest that coffee roasting (the procedure which turns green coffee beans to the dark, roasted ones from which the beverage derives) may alter the polyphenolic profile of the beans (e.g., via the Maillard reaction) and, concomitantly, their antioxidant activity. In the present study, the antioxidant activity of 13 coffee varieties was examined in both green and roasted coffee bean extracts using 2,2-diphenyl-1-picrylhydrazyl (DPPH) and 2,2'-azinobis-(3-ethylbenzothiazoline-6-sulfonic acid) $\left(\mathrm{ABTS}^{+}\right)$radical scavenging assays. In addition, 5 selected varieties were also examined for their protective effects against peroxyl and hydroxyl radical-induced DNA strand cleavage. Finally, C2C12 murine myoblasts were treated with non-cytotoxic concentrations of the most potent extract in order to examine its effects on the cellular redox status by measuring the glutathione (GSH) and
\end{abstract}

Correspondence to: Professor Demetrios Kouretas, Department of Biochemistry and Biotechnology, University of Thessaly, Ploutonos 26 and Aiolou Street, Larissa 41221, Greece

E-mail: dkouret@uth.gr

Abrreviations: GSH, glutathione; DMEM, Dulbecco's modified Eagle's medium; FBS, fetal bovine serum; $\mathrm{H}_{2} \mathrm{O}_{2}$, hydrogen peroxide; $\mathrm{O}_{2}{ }^{--}$, superoxide radical; $\mathrm{OH}^{*}$, hydroxyl radical; PBS, phosphate-buffer saline; ROO', peroxyl radical; ROS, reactive oxygen species; TPC, total polyphenolic content

Key words: coffee beans, roasting, polyphenols, melanoidins, antioxidant activity, glutathione reactive oxygen species (ROS) levels by flow cytometry. Our results revealed that, in 8 out of the 13 coffee varieties, roasting increased free radical scavenging activity as shown by DPPH and $\mathrm{ABTS}^{\bullet+}$ assays. Moreover, we found that when one coffee variety was roasted for different amounts of time, the increase in the antioxidant activity depended on the roasting time. By contrast, in 5 varieties, roasting reduced the antioxidant activity. Similar differences between the roasted and green beans were also observed in the free radical-induced DNA strand cleavage assay. The observed differences in the antioxidant activity between the different coffee varieties may be attributed to their varying polyphenolic content and composition, as well as to the different molecules produced during roasting. In addition, in the cell culture assay, the tested coffee extract led to increased GSH levels in a dose-dependent manner, indicating the enhancement of cellular antioxidant mechanisms.

\section{Introduction}

It is well-known that aerobic organisms are exposed to oxygen-free radicals, including reactive oxygen species (ROS), under various conditions (1). Thus, free radicals are produced under physiological conditions and participate in a variety of normal cellular functions, such as the regulation of signaling pathways, gene expression and apoptosis (1-3). In addition, free radicals are produced under abnormal conditions, such as in the cases of poor diet, smoking and exposure to ionizing or ultraviolet (UV) radiation. Excess free radicals in cells may interact and cause damage to proteins, lipids and DNA (4). Living organisms possess a complex endogenous defensive mechanism against free radicals that consists of both enzymatic and non-enzymatic compounds (5-7). The overproduction of free radicals may lead to oxidative stress, a pathological condition in which an imbalance between the production of free radicals and the antioxidant mechanisms is observed. Oxidative stress has been shown to be associated with a variety of diseases and pathological conditions, such as cancer, diabetes, obesity and neurodegenerative and autoimmune diseases (8-12). 
Aside from its endogenous mechanisms, an organism may also acquire antioxidant components through diet $(13,14)$. Some of the most important antioxidants, which are found particularly in plant foods, are polyphenols (15). These constitute a category of products of the plant's secondary metabolism and play an important role in a number of cellular functions $(16,17)$. When plant foods are consumed, the absorbed polyphenols may elicit a variety of important bioactivities which have beneficial effects on human health (17). Such polyphenols can also be found in coffee, which is one of the most popular beverages worldwide due to its pleasant taste and aroma; the annual production of coffee is approximately $8 \mathrm{Mt}$, and the average daily consumption is 2.3 billion cups a day (18). Traditionally, the beneficial effects of coffee on human health were mainly attributed to its most-investigated ingredient, caffeine; however, other components also contribute to its valuable properties, such as its antioxidant activity (17). The latter is attributable mainly to its polyphenolic content, with the most abundant polyphenols being chlorogenic acid (CGA) (19-21). Several studies have been performed to investigate the quantity, as well as the antioxidant and other disease-related properties, of CGA $(19,21-24)$.

However, although we are aware that coffee beans undergo roasting prior to consumption, little data exist on the effects of roasting on coffee composition, or on the differences in antioxidant activity between green and roasted beans $(25,26)$. For instance, it is known that the roasting procedure (which may be different for each variety of coffee) markedly affects CGA, leading to their hydrolysis (27). However, new compounds are formed from the products of this hydrolysis, which may alter the overall antioxidant capacity of the beans $(25,28)$. Therefore, in the present study, we aimed to examine the free radical scavenging activity of 13 coffee varieties (both green and roasted coffee beans). Furthermore, 5 selected varieties were also examined for their protective activity against free radical-induced DNA damage. Finally, C2C12 murine myoblasts were treated with non-cytotoxic concentrations of the most potent extract in order to examine its effects on the cellular redox status by measuring the glutathione (GSH) and ROS levels.

\section{Materials and methods}

Coffee beans and roasting conditions. A total of 13 coffee bean varieties were used, specifically 12 from Coffea arabica (varieties 1-5 and 7-13) and one from the Coffea canephora robusta species (variety 6). The coffee beans were roasted to different degrees. The roasting degrees depended on the roasting time and temperature, with high values indicating less roasting and low values more roasting. The roasting degrees were as follows: 110 $\left(12 \mathrm{~min} 30 \mathrm{sec} ; 210^{\circ} \mathrm{C}\right)$ for variety $1,110\left(12 \mathrm{~min} ; 210^{\circ} \mathrm{C}\right)$ for variety $2,100\left(12 \mathrm{~min} 30 \mathrm{sec} ; 211^{\circ} \mathrm{C}\right)$ for variety $3,105(12 \mathrm{~min}$; $\left.211^{\circ} \mathrm{C}\right)$ for variety $4,96\left(11 \mathrm{~min} ; 215^{\circ} \mathrm{C}\right)$ for variety $5,154(12 \mathrm{~min}$ $\left.30 \mathrm{sec} ; 218^{\circ} \mathrm{C}\right)$ for variety $6,95\left(12 \mathrm{~min} ; 208^{\circ} \mathrm{C}\right)$ for variety 7 , $95\left(12 \mathrm{~min} 30 \mathrm{sec} ; 215^{\circ} \mathrm{C}\right)$ for variety $8,101(12 \mathrm{~min} 30 \mathrm{sec}$; $\left.215^{\circ} \mathrm{C}\right)$ for variety $9,110\left(12 \mathrm{~min} 30 \mathrm{sec} ; 209^{\circ} \mathrm{C}\right)$ for variety 10 , $100\left(12 \mathrm{~min} 30 \mathrm{sec} ; 215^{\circ} \mathrm{C}\right.$ ) for variety 11 , and 144 (11 $\mathrm{min} 30 \mathrm{sec}$; $194^{\circ} \mathrm{C}$ ) for variety 12 . For variety 13,4 different roasting times (R1: 7 min $15 \mathrm{sec}$; R2: 6 min $5 \mathrm{sec}$; R3: 5 min $32 \mathrm{sec}$; R4: 3 min $52 \mathrm{sec})$ at $215^{\circ} \mathrm{C}$ were used in order to examine the effects of roasting time on the antioxidant activity.
Preparation of extracts from coffee beans. For each variety, $2 \mathrm{~g}$ of either green or roasted beans were added to $20 \mathrm{ml}$ distilled water and ground using a mortar and pestle. Each sample was sonicated for $20 \mathrm{~min}$ (70\% amplitude, $0.7 \mathrm{sec}$ cycle), and then stirred for a further $20 \mathrm{~min}$ under moderate heat $\left(35^{\circ} \mathrm{C}\right)$. The extract was separated from solid residues by centrifuging each sample $\left(7,000 \mathrm{x} \mathrm{g}, 10 \mathrm{~min}, 25^{\circ} \mathrm{C}\right)$. Finally, each extract was separated into aliquots that were kept at $-80^{\circ} \mathrm{C}$ for future use.

Assessment of the total polyphenolic content (TPC) of the extracts. The TPC of the coffee extracts was determined using Folin-Ciocalteu reagent, as previously described (29). A $20-\mu 1$ sample of extract was added to a tube containing $1 \mathrm{ml}$ deionized water. A total of $100 \mu \mathrm{l}$ Folin-Ciocalteu reagent was added to the reaction mixture, followed by incubation for $3 \mathrm{~min}$ at room temperature. Subsequently, $280 \mu 125 \% \mathrm{w} / \mathrm{v}$ sodium carbonate solution and $600 \mu \mathrm{l}$ deionized water were added to the mixture. Following $1 \mathrm{~h}$ of incubation at room temperature in the dark, the absorbance was measured at $765 \mathrm{~nm}$ vs. a blank containing Folin-Ciocalteu reagent and distilled water without the extract. The measurement of absorbance was conducted on a Hitachi U-1900 radio beam spectrophotometer (serial no. 2023-029; Hitachi, Tokyo, Japan). The optical density of the sample $(20 \mu \mathrm{l})$ in $25 \% \mathrm{w} / \mathrm{v}$ solution of sodium carbonate $(280 \mu \mathrm{l})$ and distilled water $(1.7 \mathrm{ml})$ at $765 \mathrm{~nm}$ was also measured. The TPC was determined using a standard curve of absorbance values correlated with standard concentrations $(50-1500 \mu \mathrm{g} / \mathrm{ml})$ of gallic acid. The TPC is presented as $\mu \mathrm{g}$ of gallic acid equivalents per $\mathrm{mg}$ of extract in percentage form.

Assessment of CGA concentration of the coffee extracts. A liquid chromatography (LC)-mass spectrometry (MS; 2010) system was used for the analysis of CGA. CGA ( $\geq 95 \%)$ was also purchased from Sigma-Adrich (St. Louis, MO, USA) for making stock solutions. Stock solutions of CGA at a concentration of $100 \mathrm{ppm}$ were prepared in methanol. The working solutions of the analytes $(0,0.5,1,2.5$ and $5 \mathrm{ppm})$ were prepared by further dilutions of the stock solutions. All solutions were stored at $-20^{\circ} \mathrm{C}$ in the dark. To a volume of $50 \mu 1$ of each sample, $950 \mu 1$ of methanol were added, following by vortexing and centrifugation at $14,000 \mathrm{rpm}$ for $5 \mathrm{~min} ; 20 \mu \mathrm{l}$ of the supernatant was injected into the LC system for analysis. The system comprised of a binary LC pump (Shimadzu Prominence LC; Shimadzu, Kyoto, Japan), a vacuum degasser, an autosampler, a diode array detector (SPD-M20A Prominence; Shimadzu, Kyoto, Japan; serial no. L201545) and a column oven. A gradient of $0.1 \%$ formic acid in water (solvent $\mathrm{A}$ ) and methanol (solvent $\mathrm{B}$ ) was selected as the mobile phase, with a flow rate of $0.7 \mathrm{ml} / \mathrm{min}$ : starting at $20 \%$ solvent B (1 min), 95\% solvent B (13 min linear ramp), and finally $20 \%$ solvent $B$ (13.01 min). The separation of the analytes was achieved on a Discovery ${ }^{\circledR}$ C18 HPLC column $(250 \times 4.6 \mathrm{~mm}, 5 \mu \mathrm{m})$ thermostated at $30^{\circ} \mathrm{C}$. A diode array detector was used for the determination of the analytes. The maximum wavelength for CGA was $320 \mathrm{~nm}$. The CGA retention time was $8.93 \mathrm{~min}$.

\section{2,2-diphenyl-1-picrylhydrazyl (DPPH) radical scavenging} assay. The free-radical scavenging capacity (RSC) of the extracts was evaluated by DPPH radical assay, as previously described (29). Briefly, a $1.0 \mathrm{ml}$ freshly prepared methanolic 
solution of DPPH radical $(100 \mu \mathrm{M})$ was mixed with the tested extract solution at various concentrations $(0.5-100 \mu \mathrm{g} / \mathrm{ml})$. The contents were vigorously mixed, incubated at room temperature in the dark for $20 \mathrm{~min}$, and the absorbance was measured at $517 \mathrm{~nm}$. The measurement was conducted on a Hitachi U-1900 radio beam spectrophotometer (Hitachi). In each experiment, the tested sample alone in methanol was used as a blank and DPPH alone in methanol was used as the control.

The percentage RSC of the tested extracts was calculated using the following equation: $\operatorname{RSC}(\%)=\left[\left(\mathrm{A}_{\text {control }}-\right.\right.$ $\left.\left.\mathrm{A}_{\text {sample }}\right) / \mathrm{A}_{\text {control }}\right] \mathrm{x} 100$, where $\mathrm{A}_{\text {control }}$ and $\mathrm{A}_{\text {sample }}$ are the absorbance values of the control and the test sample, respectively. Moreover, in order to compare the radical scavenging efficiency of the extracts, the $\mathrm{IC}_{50}$ value indicating the concentration that caused $50 \%$ scavenging of the DPPH radical was calculated from the graph-plotted RSC percentage against the extract concentration. All experiments were carried out in triplicate and on at least two separate occasions.

2,2'-Azinobis-(3-ethylbenzothiazoline-6-sulfonic acid) $\left(\right.$ ABTS $\left.^{\circ+}\right)$ radical scavenging assay. The $\mathrm{ABTS}^{\bullet+} \mathrm{RSC}$ of the extract was determined as previously described in the study by Cano et al (31) with minor modifications. Briefly, the reaction was carried out in $1 \mathrm{ml}$ distilled water containing ABTS $^{\bullet+}(1 \mathrm{mM})$, hydrogen peroxide $\left(\mathrm{H}_{2} \mathrm{O}_{2}\right)(30 \mu \mathrm{M})$ and horseradish peroxidase $(6 \mu \mathrm{M})$ in $50 \mathrm{mM}$ phosphate-buffered saline (PBS; $\mathrm{pH}$ 7.5). The solution was vigorously mixed followed by incubation at room temperature in the dark for 45 min until $\mathrm{ABTS}^{-+}$radical formation occurred. Subsequently, $10 \mu \mathrm{l}$ extracts, of various concentrations, were added to the reaction mixture and the absorbance at $730 \mathrm{~nm}$ was read. The measurement was conducted on a Hitachi U-1900 radio beam spectrophotometer (Hitachi). In each experiment, the tested sample in distilled water containing $\mathrm{ABTS}^{\bullet+}$ and $\mathrm{H}_{2} \mathrm{O}_{2}$ in 50 mM PBS-pH 7.5 was used as a blank, and the ABTS ${ }^{*+}$ radical solution with $\mathrm{H}_{2} \mathrm{O}$ was used as the control. The $\mathrm{RSC}$ percentage and the $\mathrm{IC}_{50}$ values were determined as described above for the DPPH method. All experiments were carried out in triplicate and on at least two separate occasions.

Hydroxyl radical-induced DNA plasmid strand cleavage. DNA strand breakage was measured by the conversion of supercoiled pBluescript $(\mathrm{SK}+)$ plasmid double-stranded DNA to the open circular form. Hydroxyl radical-induced DNA relaxation assay was performed according to the method described in the study by Keum et al (32) with some modifications. The reaction mixture $(10 \mu \mathrm{l})$ consisted of $1 \mu \mathrm{g}$ pBluescript $(\mathrm{SK}+)$ plasmid DNA, $10 \mathrm{mM}$ Tris-HCl-1 mM EDTA, the tested extract at various concentrations $(600,1,000,1,500,2,000,3,300$ and $6,000 \mu \mathrm{g} / \mathrm{ml})$ and $40 \mathrm{mM} \mathrm{H}_{2} \mathrm{O}_{2}$. Hydroxyl radicals $\left(\mathrm{OH}^{*}\right)$ were generated from $\mathrm{UV}$ photolysis of $\mathrm{H}_{2} \mathrm{O}_{2}$ following irradiation of the reaction mixture with a $300 \mathrm{~W}$ UV lamp (OSRAM GmbH, Munich, Germany) for $3 \mathrm{~min}$ at a distance of $50 \mathrm{~cm}$. The reaction was terminated by the addition of $3 \mu$ loading buffer ( $0.25 \%$ bromophenol blue and $30 \%$ glycerol) and analyzed by $0.8 \%$ agarose gel electrophoresis at $80 \mathrm{~V}$ for $1 \mathrm{~h}$. The gels were stained with ethidium bromide $(0.5 \mu \mathrm{g} / \mathrm{ml})$, destained with water, photographed and analyzed by UV transillumination using the Alpha Innotech Multiimage (ProteinSimple, San Jose, CA, USA). In addition, pBluescript (SK+) plasmid DNA was treated with each extract alone, at the highest concentration used in the assay, in order to examine the effects of the extracts on plasmid DNA conformation. It should be noted that isolated pBluescript $(\mathrm{SK}+)$ plasmid DNA contained approximately $10 \%$ open-circular DNA prior to treatment. Each experiment was repeated at least 3 times. The preventive activity of the tested extracts against hydroxyl radical-induced DNA strand breakage was assessed by measuring the inhibition of the conversion of supercoiled conformation to the open-circular form. The percentage inhibition of radical-induced DNA strand cleavage by the extracts was calculated using the following formula: \% inhibition $=\left[\left(\mathrm{S}-\mathrm{S}_{\mathrm{o}}\right) /\left(\mathrm{S}_{\text {control }}-\mathrm{S}_{\mathrm{o}}\right)\right] \times 100$, where $\mathrm{S}_{\text {control }}$ is the percentage of supercoiled DNA in the negative control sample (plasmid DNA alone), $\mathrm{S}_{\mathrm{o}}$ is the percentage of supercoiled plasmid DNA in the positive control sample (without tested extracts but in the presence of the radical initiating factor), and $\mathrm{S}$ is the percentage of supercoiled plasmid DNA in the sample with the tested extracts and the radical initiating factor. Moreover, in order to compare the percentage inhibition of the extracts, the $\mathrm{IC}_{50}$ value indicating the concentration that caused 50\% scavenging of the DPPH radical was calculated by comparing the graph-plotted percentage inhibition to the extract concentration. All experiments were carried out in triplicate and on at least two separate occasions.

Peroxyl radical-induced DNA plasmid strand cleavage. The assay was performed using the procedure previously described in the study by Chang et al (33). Peroxyl radicals $\left(\mathrm{ROO}^{\circ}\right)$ were generated from the thermal decomposition of 2,2'-azobis(2-amidinopropane) dihydrochloride (AAPH). The reaction mixture $(10 \mu \mathrm{l})$ containing $1 \mu \mathrm{g}$ pBluescript (SK+) plasmid DNA, $2.5 \mathrm{mM}$ AAPH in PBS and the tested extract at various concentrations $(50,60,75,100,150$ and $300 \mu \mathrm{g} / \mathrm{ml})$ was incubated in the dark for $45 \mathrm{~min}$ at $37^{\circ} \mathrm{C}$. Following incubation, the reaction was terminated by the addition of $3 \mu$ l loading buffer $(0.25 \%$ bromophenol blue and $30 \%$ glycerol $)$ and analyzed by gel electrophoresis. Each experiment was repeated 3 times. The preventive effects of the tested extracts against peroxyl radical-induced DNA strand breakage were assessed as described above for hydroxyl radical-induced DNA strand breakage.

Cell culture conditions. The $\mathrm{C} 2 \mathrm{C} 12$ murine myoblasts were a gift from Professor Koutsilieris (National and Kapodistrian University of Athens, Athens, Greece). The cells were cultured in Dulbecco's modified Eagle's medium (DMEM), containing $10 \%$ (v/v) fetal bovine serum (FBS), 2 mM L-glutamine, $100 \mathrm{U} / \mathrm{ml}$ of penicillin and $100 \mathrm{U} / \mathrm{ml}$ streptomycin (all from Gibco, Paisley, UK) in plastic disposable tissue culture flasks at $37^{\circ} \mathrm{C}$ in an atmosphere with $5 \%$ carbon dioxide.

XTT assay. Cell viability was assessed using an XTT assay kit (Roche, Mannheim, Germany). Briefly, the C2C12 cells were subcultured in a 96-well plate with $1 \times 10^{4}$ cells per well in DMEM. Following $24 \mathrm{~h}$ of incubation, the cells were treated with various concentrations of the coffee extract in serum-free DMEM for $24 \mathrm{~h}$. Subsequently, $50 \mathrm{ml} \mathrm{XTT} \mathrm{test}$ solution, which was prepared by mixing $50 \mathrm{ml}$ XTT labeling reagent with $1 \mathrm{ml}$ electron coupling reagent, were added to each well. Following $4 \mathrm{~h}$ of incubation, absorbance was measured 
at $450 \mathrm{~nm}$ and also at $690 \mathrm{~nm}$ as a reference wavelength in a BioTek ELx800 microplate reader (BioTek Instruments, Inc., Winooski, VT, USA). Serum-free DMEM was used as a negative control. In addition, the absorbance of the grape-extract concentration alone in serum-free DMEM and XTT test solution was tested at $450 \mathrm{~nm}$. The absorbance values of the grape extracts alone were subtracted from those derived from cell treatment with coffee extract. Data were calculated as the percentage of inhibition using the following formula: inhibition $(\%)=\left[\left(\mathrm{OD}_{\text {control }}-\mathrm{OD}_{\text {sample }}\right) / \mathrm{OD}_{\text {control }}\right] \times 100$, where $\mathrm{OD}_{\text {control }}$ and $\mathrm{OD}_{\text {sample }}$ indicate the optical density of the negative control and the tested compounds, respectively. All experiments were carried out in triplicate and on two separate occasions.

Assessment of GSH and ROS levels by flow cytometry. The intracellular GSH and ROS levels were assessed using mercury orange and 2,7-dichlorofluorescein diacetate (DCF-DA), respectively. The fluorescent mercury orange binds directly to GSH, while DCF-DA within cells is deacetylated by esterases and is further converted to fluorescent DCF by the oxidative action of ROS. A 400-mM stock solution of mercury orange was prepared in acetone and stored at $4^{\circ} \mathrm{C}$, and a fresh $400-\mathrm{mM}$ stock solution of DCF-DA was prepared in methanol. To measure the GSH and ROS levels, the cells were resuspended in PBS at $1 \times 10^{6}$ cells $/ \mathrm{ml}$ and incubated in the presence of mercury orange $(40 \mu \mathrm{M})$ or DCF-DA $(10 \mu \mathrm{M})$ in the dark at $37^{\circ} \mathrm{C}$ for $30 \mathrm{~min}$. The cells were then washed, resuspended in PBS, and subjected to flow cytometric analysis using a FACSCalibur flow cytometer (Becton-Dickinson, Franklin Lakes, NJ, USA) with excitation and emission wavelengths at 488 and $530 \mathrm{~nm}$ for ROS and at 488 and $580 \mathrm{~nm}$ for GSH, respectively. In addition, forward-angle and right-angle light scattering showing the cell size and cell internal complexity, respectively, were measured. The cells were analyzed at a flow rate of 1,000 events/sec. Analyses were performed on 10,000 cells per sample, and the fluorescence intensities were measured on a logarithmic scale of 4 decades of log of fluorescence. Data were analyzed using BD Cell Quest software (Becton-Dickinson). Each experiment was repeated at least 3 times.

Statistical analysis. All results are expressed as the means \pm standard deviation. A Spearman's correlation analysis for examining the results from the TPC, DPPH and ABTS ${ }^{+}$ assays was performed. A P-value $<0.05$ was considered to indicate a statistically significant difference. In addition, one-way ANOVA was applied, followed by Tukey's test for multiple pair-wise comparisons using SPSS software (SPSS, Inc., Chicago, IL, USA).

\section{Results and Discussion}

The TPC was determined in each coffee variety before and after roasting (Fig. 1). The TPC percentage by mass varied from 2.7 to $4.7 \%$ for the roasted beans, with a mean value of $3.8 \%$, whereas for the green beans, the values varied from 3.2 to $5.2 \%$, with a mean value of $3.8 \%$. In 7 of the 13 varieties, the green coffee beans had higher amounts of polyphenols, as was expected (Fig. 1A). However, in the remaining 6, the roasted beans had more polyphenols than their respective green beans (Fig. 1B and C). The polyphenolic percentages obtained
A

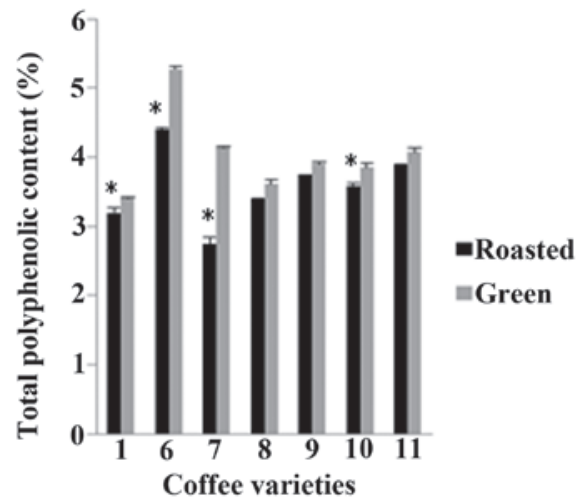

B

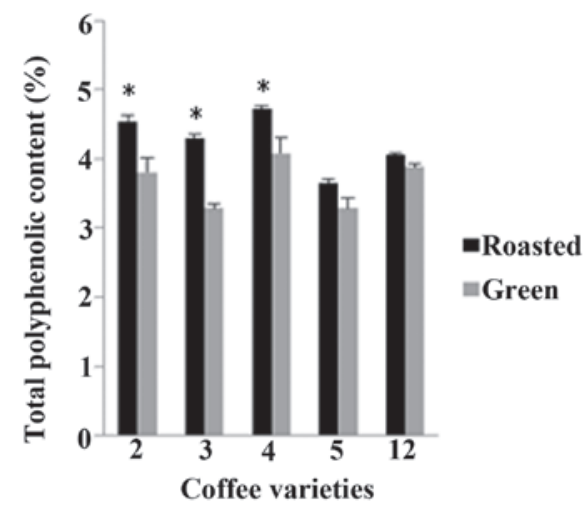

C

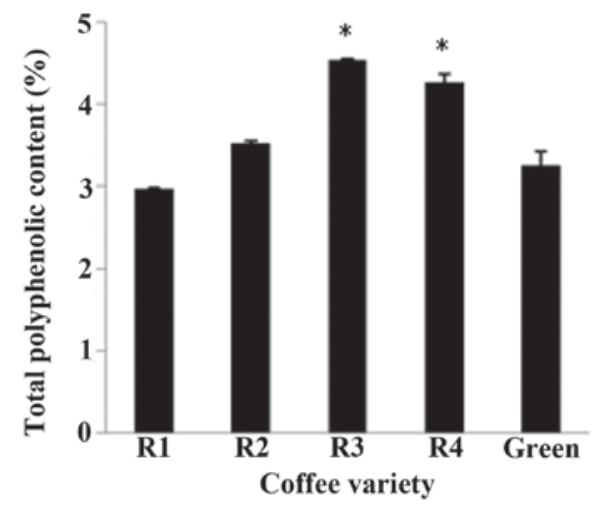

Figure 1. Total polyphenolic content (TPC) of each variety of coffee. TPC is expressed as a percentage by mass of each tested sample, as measured by Folin-Ciocalteau assay. (A) Varieties of green beans which had a higher TPC compared with their respective roasted beans. (B) Varieties of roasted seeds which had a higher TPC. (C) Effects of roasting time on the TPC of variety 13. The roasting times were as follows: R1, $7 \mathrm{~min} 15 \mathrm{sec}$; R2, 6 min $5 \mathrm{sec}$; R3, $5 \mathrm{~min} 32 \mathrm{sec}$; R4, 3 min $52 \mathrm{sec}$. All data are expressed as the means \pm SD. ${ }^{*} \mathrm{P}<0.05$ indicated a statistically significant difference between roasted beans and the respective green beans.

in the present study are in agreement with those presented in the relevant literature, despite the fact that, depending on the variety, large variations have been detected $(27,34,35)$.

Following the determination of the polyphenolic content, the antioxidant activity of each sample was evaluated using DPPH and $\mathrm{ABTS}^{\circ+}$ assays (Figs. 2 and 3). In order to examine the antioxidant potency of the polyphenols contained in each coffee sample, the $\mathrm{IC}_{50}$ value obtained from the assays was divided by the amount of polyphenols contained in each $\mathrm{mg}$ of the respective coffee extract. According to both assays, in 8 of the 13 varieties, the roasted beans exhibited an increased antioxidant activity compared with their respective green 
A

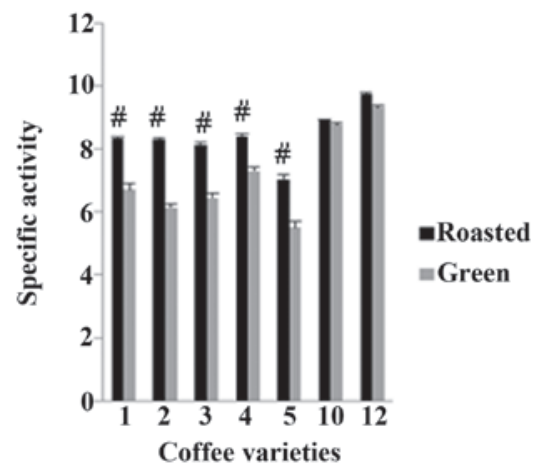

B

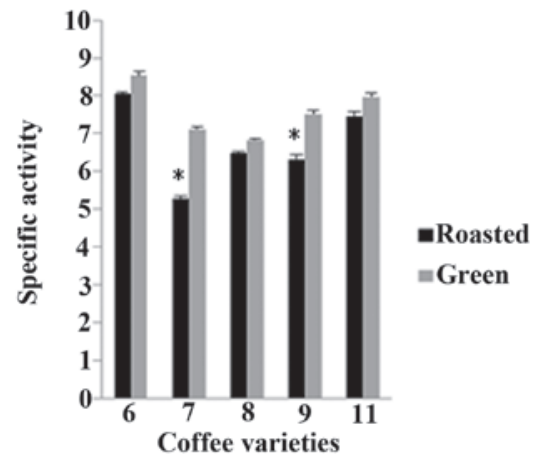

C

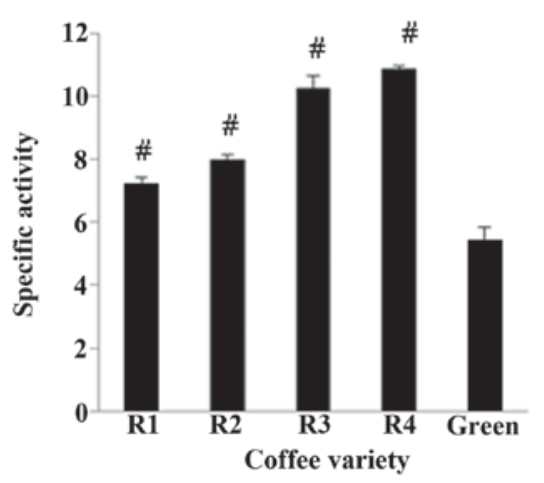

Figure 2. Antioxidant activity as assessed using DPPH assay. The specific activity of each variety is shown, as measured in units of activity per mg of coffee extract. A unit represents the amount of polyphenols required to scavenge $50 \%$ of the DPPH radical. (A) Varieties of roasted seeds which exhibited higher levels of activity compared with their respective green beans. (B) Varieties of green beans which exhibited higher levels of activity. (C) Effects of roasting time on DPPH radical scavenging by variety 13 . The roasting times were as follows: R1, $7 \mathrm{~min} 15 \mathrm{sec}$; R2, 6 min $5 \mathrm{sec}$; R3, 5 min $32 \mathrm{sec} ; \mathrm{R} 4,3 \mathrm{~min} 52 \mathrm{sec}$. All data are expressed as the means $\pm \mathrm{SD}$. ${ }^{*} \mathrm{P}<0.05$ and ${ }^{\#} \mathrm{P}<0.01$ indicated a statistically significant difference between roasted beans and the respective green beans.

beans (Fig. 1A and $\mathrm{C}$ and Fig. 2A and $\mathrm{C}$ ), whereas in the remaining 5 varieties, the opposite was observed (Figs. 2B and 3B). Specifically, in varieties 1,2,3,4 and 5, the roasted beans exhibited a significant $(\mathrm{P}<0.01)$ increase in antioxidant activity compared to the green beans by 24.1,35.1,26.0,15.2 and 27.9\%, respectively, in the DPPH assay, and in the $\mathrm{ABTS}^{\circ+}$ assay, this increase was 30.4, 36.2, 42.0, 25.2 and $34.1 \%$, respectively. By contrast, in varieties 7 and 9 , the antioxidant activity decreased significantly $(\mathrm{P}<0.05)$ after roasting, by 26.0 and $16.0 \%$, respectively, for the DPPH assay, whereas in varieties 7 and 8 , the decrease was 16.4 and $11.0 \%$, respectively, in the $\mathrm{ABTS}^{\circ+}$ assay. The differences between the DPPH and $\mathrm{ABTS}^{++}$assays
A

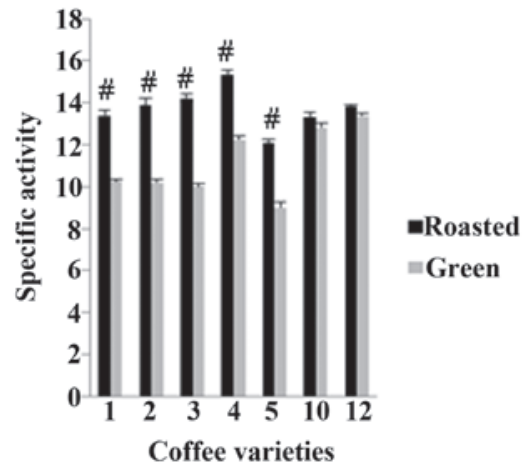

B

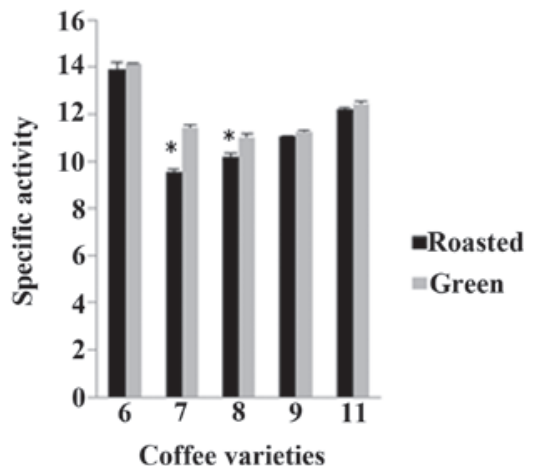

C

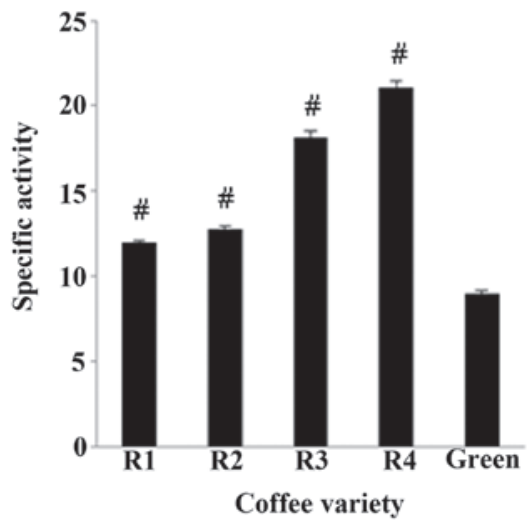

Figure 3. Antioxidant activity as assessed using ABTS $^{*+}$ assay. The specific activity of each variety is shown, measured in units of activity per mg of coffee extract. A unit represents the amount of polyphenols required to scavenge $50 \%$ of the $\mathrm{ABTS}^{\bullet+}$ radical. (A) Varieties of roasted seeds which exhibited higher levels of activity compared with the respective green beans. (B) Varieties of green beans which exhibited higher levels of activity. (C) Effects of roasting time on $\mathrm{ABTS}^{-+}$radical scavenging by variety 13 . The roasting times were as follows: R1, 7 min $15 \mathrm{sec}$; R2, 6 min $5 \mathrm{sec}$; R3, $5 \mathrm{~min} 32 \mathrm{sec}$; R4, $3 \mathrm{~min} 52 \mathrm{sec}$. All data are expressed as the means \pm SD. ${ }^{*} \mathrm{P}<0.05$ and ${ }^{\#} \mathrm{P}<0.01$ indicated a statistically significant difference between roasted beans and the respective green beans.

may be ascribed to the varying reactivity of these 2 radicals to the components of each coffee sample. The fact that roasting increased the antioxidant activity in some samples and reduced it in others may be explained by the different phenolic composition of these varieties. It is well known that roasting greatly affects the chemical composition of the coffee beans due to the high temperatures used $(28,36)$. For example, new compounds, such as melanoidins, are formed, which exhibit antioxidant activity, whereas other ingredients, such as CGAs are broken down $(25,37)$.

Moreover, we noted that the results from both DPPH and ABTS $^{-+}$assays significantly correlated with the TPC (Table I). 
Table I. Correlation coefficient ( $\mathrm{r}$ ) between values of TPC, DPPH and $\mathrm{ABTS}^{\bullet+}$ assays.

\begin{tabular}{lc}
\hline Assays & Correlation coefficient (r) \\
\hline TPC-DPPH & $0.647^{\mathrm{a}}$ \\
TPC-ABTS $^{\circ+}$ & $0.766^{\mathrm{a}}$ \\
DPPH-ABTS $^{\cdot+}$ & $0.926^{\mathrm{a}}$
\end{tabular}

${ }^{a} \mathrm{P}<0.05$ indicates a statistically significant difference. TPC, total polyphenolic content.

Specifically, the correlation coefficient $(r)$ was $0.647(\mathrm{P}<0.01)$ between TPC and DPPH, $0.766(\mathrm{P}<0.01)$ between TPC and $\mathrm{ABTS}^{\circ+}$, and $0.926(\mathrm{P}<0.01)$ between $\mathrm{DPPH}$ and ABTS $^{++}$(Table I). The correlations between the TPC and both the free radical scavenging assays, DPPH and $\mathrm{ABTS}^{\circ+}$, indicated that there was an association between the total amount of polyphenols and the antioxidant activity, that is, higher amounts of polyphenols led to enhanced potency. In addition, the correlation between DPPH and $\mathrm{ABTS}^{\circ+}$ suggests that the same compounds of the extracts are likely responsible for the scavenging of both free radicals.

For variety 13, there were 4 different roasted bean samples, and each one was roasted for a different amount of time at $215^{\circ} \mathrm{C}$. The results revealed that the antioxidant activity of the beans was dependent on the roasting time (Figs. 2C and 3C). More specifically, for all 4 samples, the roasted beans exhibited significantly $(\mathrm{P}<0.01)$ higher levels of activity than the green ones, at roasting times of $7 \mathrm{~min} 15 \mathrm{sec}(\mathrm{R} 1), 6 \mathrm{~min} 5 \mathrm{sec}(\mathrm{R} 2)$, $5 \mathrm{~min} 32 \mathrm{sec}$ (R3) and $3 \mathrm{~min} 52 \mathrm{sec}$ (R4) by 32.8, 46.2, 87.9 and $99.6 \%$, respectively for DPPH assay, and by 33.4, 42.4, 102.0 and $135.0 \%$, respectively for $\mathrm{ABTS}^{\circ+}$ assay (Figs. 2C and $3 \mathrm{C}$ ). The roasting conditions which were used for these beans are all within the range of those typically used when making coffee beverages. The considerable differences observed under varying roasting conditions are in accordance with those presented in other studies $(36,38,39)$. In addition, an LC-MS analysis was performed to examine the effect of roasting on the levels of CGA. For this analysis, 2 samples from variety 13 were used: the green extract and a sample roasted for $3 \mathrm{~min}$ and $52 \mathrm{sec}(\mathrm{R} 4)$ at $215^{\circ} \mathrm{C}$. According to the results, CGA diminished from $2028.4 \mathrm{ppm}$ in the green beans to $38.8 \mathrm{ppm}$ in the roasted sample (Fig. 4). This difference denotes the importance of novel antioxidant substances that are formed during the roasting procedure (e.g., melanoidins). Specifically, although one of the most prominent antioxidant compounds in green beans is practically non-existent in the roasted ones, the latter exhibited higher levels of antioxidant activity. It has previously been reported that polyphenolic compounds can be incorporated into melanoidins during roasting, either as intact units or following their breakdown to simpler phenols (40).
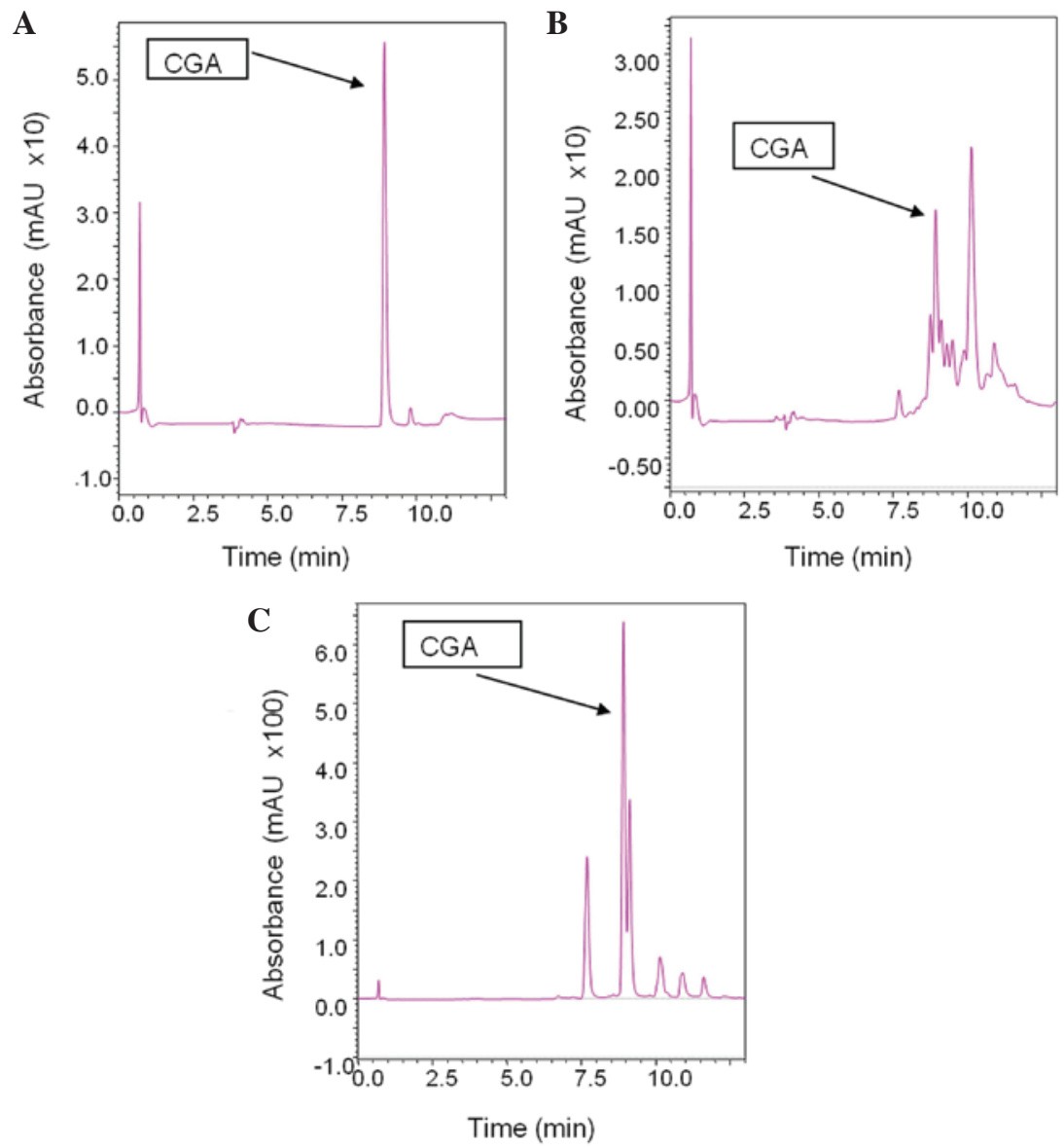

Figure 4. Liquid chromatography (LC)-mass spectrometry (MS) chromatograms of chlorogenic acid (CGA) of (A) standard solution at the concentration of $10 \mathrm{ppm},(\mathrm{B})$ roasted coffee at the found concentration of $38.8 \mathrm{ppm}$, and (C) green coffee at the found concentration of $2028.4 \mathrm{ppm}$. 
A

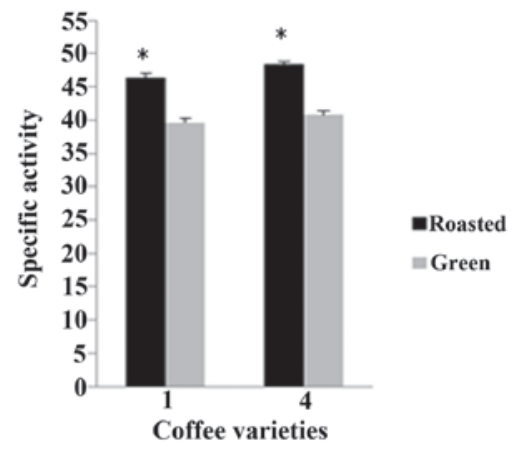

B

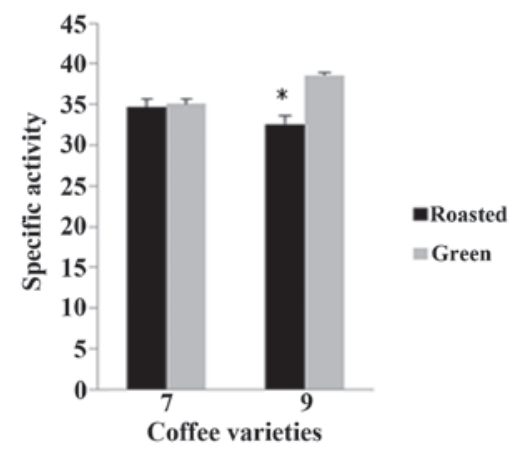

C

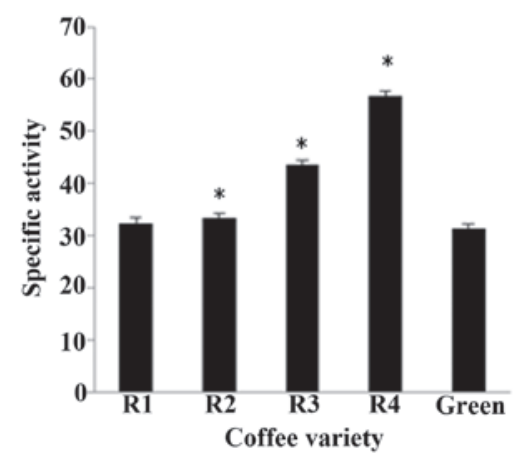

Figure 5. Protection from hydroxyl radical-induced DNA damage as assessed using a DNA plasmid strand cleavage assay. The specific activity of each variety is shown, measured in units of activity per mg of coffee extract. A unit represents the amount of polyphenols required to prevent plasmid relaxation by $50 \%$. (A) Varieties in which roasted seeds which exhibited higher levels of activity compared with their respective green beans. (B) Varieties of green beans which exhibited higher levels of activity. (C) Effects of roasting time on protection from hydroxyl radical-induced DNA damage by variety 13 . The roasting times were as follows: R1, $7 \mathrm{~min} 15 \mathrm{sec}$; R2, 6 min $5 \mathrm{sec}$; R3, $5 \mathrm{~min}$ $32 \mathrm{sec} ; \mathrm{R} 4,3 \mathrm{~min} 52 \mathrm{sec}$. All data are expressed as the means $\pm \mathrm{SD}$. ${ }^{*} \mathrm{P}<0.01$ indicated a statistically significant difference between roasted beans and the respective green beans.

To further investigate the antioxidant capacity of the coffee extracts, 2 assays assessing the protective effects of the extracts against ROS-induced DNA damage were carried out. For the ROO- and $\mathrm{OH}^{-}$-induced DNA plasmid strand breakage assays, 5 varieties were selected, namely 1 and 4 (those varieties in which higher activity was observed for the roasted beans compared to the green beans in the DPPH and ABTS ${ }^{++}$ assays), 7 and 9 (where the green beans were more potent than the roasted beans according to DPPH and $\mathrm{ABTS}^{\circ+}$ assays), and variety 13 , in which the effect of the roasting time was tested (Figs. 5 and 6). These 2 methods yielded similar results with the DPPH and $\mathrm{ABTS}^{-+}$assays. Specifically, in the case of $\mathrm{OH}^{*}$, the roasted beans of varieties 1 and 4 exhibited higher
A

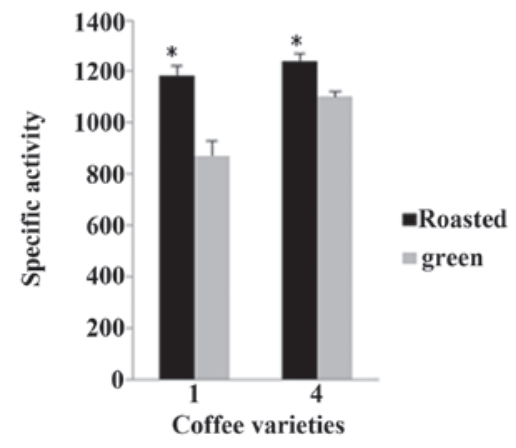

B

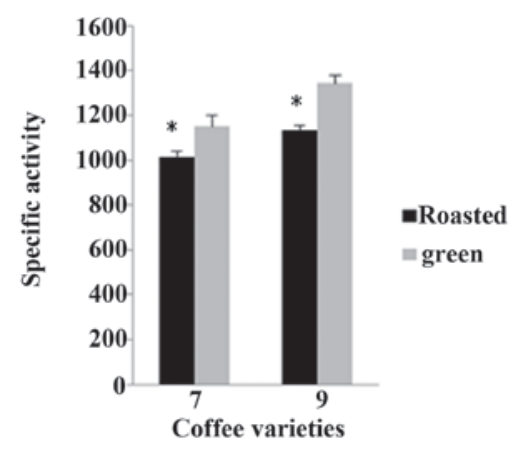

C

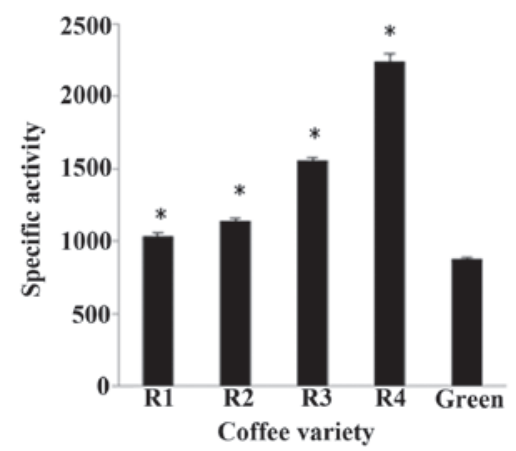

Figure 6. Protection from peroxyl radical-induced DNA damage as assessed using DNA plasmid strand cleavage assay. The specific activity of each variety is shown, measured in units of activity per mg of coffee extract. A unit represents the amount of polyphenols required to prevent plasmid relaxation by $50 \%$. (A) Varieties of roasted seeds which exhibited higher levels of activity compared with their respective green beans. (B) Varieties of green beans which exhibited higher levels of activity. (C) Effects of roasting time on protection from peroxyl radical-induced DNA damage by variety 13 . The roasting times were as follows: R1, $7 \mathrm{~min} 15 \mathrm{sec}$; R2, 6 min $5 \mathrm{sec}$; R3, $5 \mathrm{~min}$ $32 \mathrm{sec}$; R4, $3 \mathrm{~min} 52 \mathrm{sec}$. All data are expressed as the means $\pm \mathrm{SD}$. ${ }^{*} \mathrm{P}<0.01$ indicated a statistically significant difference between roasted beans and the respective green beans.

specific activity by 17.0 and $19.0 \%$, respectively, compared to the green beans, whereas in varieties 7 and 9 the green beans had a higher activity by 4.1 and $18.5 \%$, respectively, than the roasted beans (Fig. 5A and B). Moreover, for variety 13, all 4 groups of roasted beans had significantly $(\mathrm{P}<0.05)$ higher activities than the green ones, by $3.2,6.2,39$ and $81.1 \%$ for R1, R2, R3 and R4 time points of roasting, respectively (Fig. 5C). As for the assay using ROO', again in varieties 1 and 4 the roasted beans higher activities by 35.6 and $12.7 \%$, respectively, compared to the green beans, whereas in varieties 7 and 9 , the green beans exhibited higher levels of activity, by 13.2 and $18.4 \%$, respectively, than the roasted beans (Fig. 6A and B). In addition, in variety 13 the roasted beans exhibited 


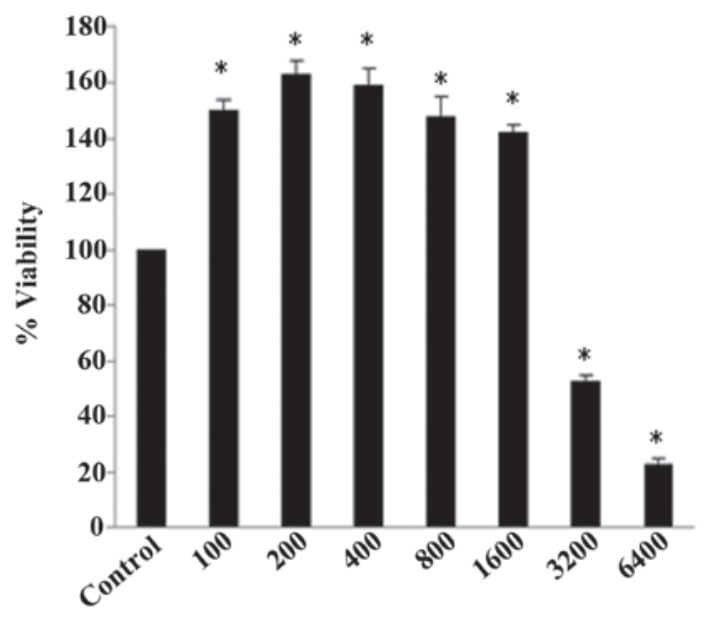

Coffee extract $(\mu \mathrm{g} / \mathrm{ml})$

Figure 7. Assessment of effects of variety 13 roasted extract (roasting conditions: $3 \mathrm{~min} 52 \mathrm{sec} ; 215^{\circ} \mathrm{C}$ ) on the viability of $\mathrm{C} 2 \mathrm{C} 12$ murine myoblasts after $24 \mathrm{~h}$ treatment. Cytotoxicity was estimated via XTT assay. All data are expressed as the means \pm SD. ${ }^{*} \mathrm{P}<0.01$ indicated a statistically significant difference compared to the control. significantly higher levels of activity compared with the green ones, by 17.0, 29.1, 77.3 and $154.0 \%$ for R1, R2, R3 and R4 time points of roasting, respectively (Fig. 6C).

Thus, we noted that all the tested coffee extracts exhibited protective activity against free radical-induced DNA damage, with the most potent being the less roasted sample from variety 13 (R4). As shown in Figs. 5 and 6, the much lower specific activities observed against $\mathrm{OH}^{\circ}$-induced DNA strand breaks may be due to the high reaction rate of $\mathrm{OH}^{*}$ with DNA, and thus it is more difficult for antioxidant molecules to exert their protective effects (41). To the best of our knowledge, this is the first study to report the protective effects of coffee extracts against DNA damage induced by $\mathrm{OH}^{*}$ and $\mathrm{ROO}^{\circ}$ radicals. However, other studies have been performed using different oxidants, and the oxidants in these coffee extracts also exerted a significant protective effect against mutagenesis (42). Specifically, coffee inhibited tert-butylhydroperoxide-induced mutagenicity in Salmonella typhimurium strains TA100 and TA102. This activity was partly attributed to cafestol and kahweol, two diterpenes commonly found in coffee $(43,44)$.
$\mathbf{A}$
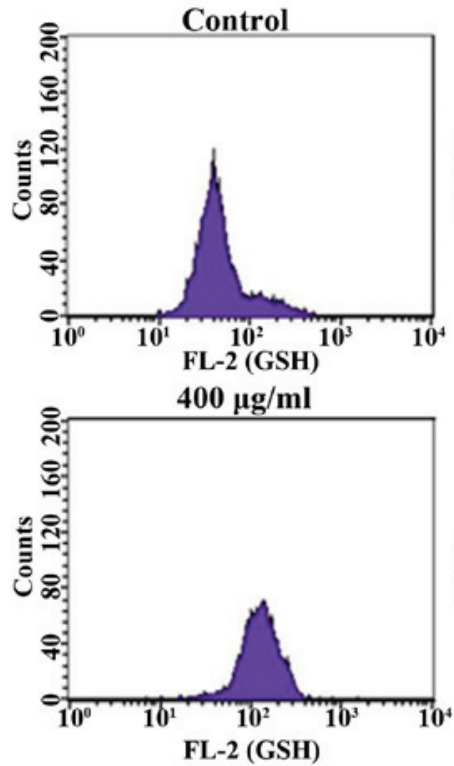
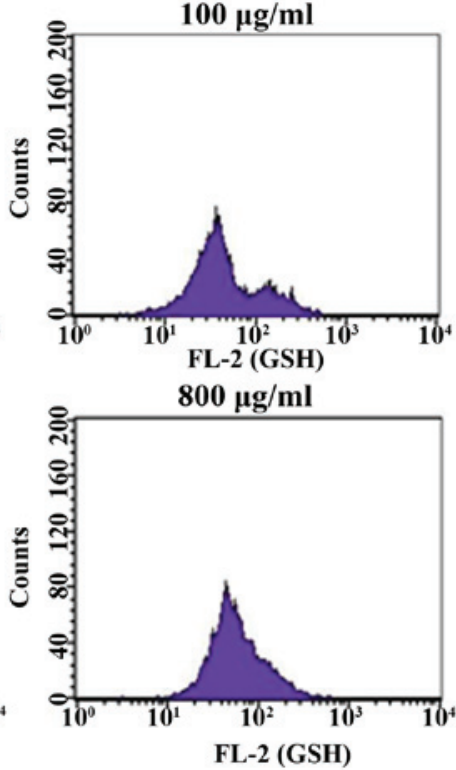
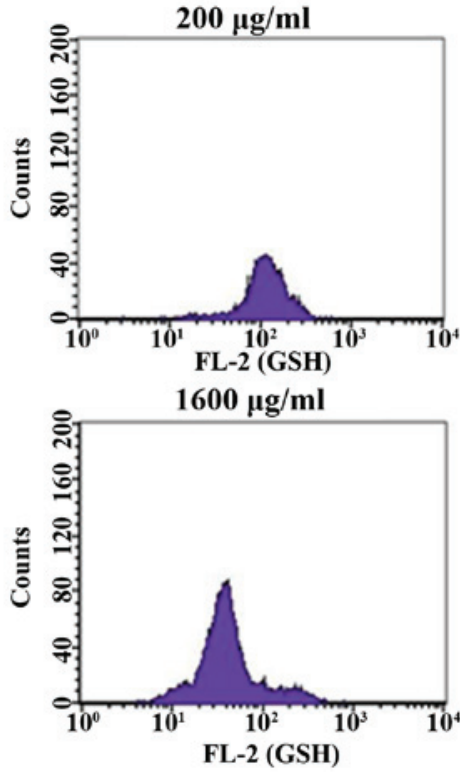

B
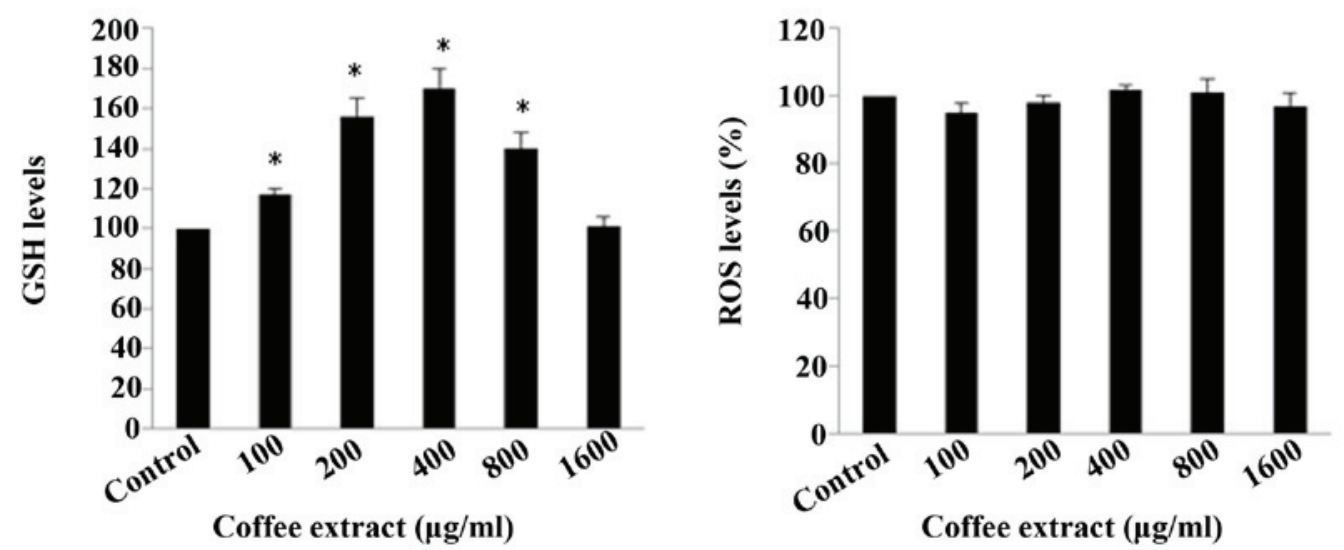

Figure 8. Effects of variety 13 roasted extract (roasting conditions: 3 min $52 \mathrm{sec} ; 215^{\circ} \mathrm{C}$ ) after treatment for 24 h on glutathione (GSH) and reactive oxygen species (ROS) levels in C2C12 cells, as assessed by flow cytometry. (A) The histogram of cell counts versus fluorescence of 10,000 cells, as analyzed by the flow cytometer in order to detect GSH levels. FL-2 represents the detection of fluorescence using 488 and $580 \mathrm{~nm}$ as the excitation and emission wavelength, respectively. (B) Bar charts showing the GSH and ROS levels, as calculated by BD Cell Quest software. All results are expressed as the means \pm SD. ${ }^{*} \mathrm{P}<0.05$ indicated a statistically significant difference between roasted beans and the control. 
To summarize, all coffee extracts exhibited an antioxidant activity similar to that observed in previous studies by our research group on polyphenolic extracts; the antioxidant activity of the extracts was comparable to that of grapes (45) and pomegranates (unpublished data).

The most potent antioxidant extract [variety 13 , roasted for $3 \mathrm{~min}$ and $52 \mathrm{sec}$ at $215^{\circ} \mathrm{C}$ (R4)] was selected in order to examine its effects on the cellular redox status (specifically in $\mathrm{C} 2 \mathrm{C} 12$ murine myoblasts) by assessing the GSH and ROS levels by flow cytometry. Non-cytotoxic concentrations were used (according to the results of the XTT assay) and, more specifically, the non-cytotoxic concentrations ranged from 100-1,600 $\mu \mathrm{g} / \mathrm{ml}$ extract (Fig. 7). The results of flow cytometric analysis revealed that the GSH levels were increased significantly $(\mathrm{P}<0.05)$, by 17 , 56,70 and $40 \%$ at $100,200,400$ and $800 \mu \mathrm{g} / \mathrm{ml}$ extract, respectively, compared to the control (Fig. 8). Although the extract increased the levels of the antioxidant molecule, GSH, the ROS levels were not significant affected by the extract (Fig. 8). In previous studies of ours, we also found that the ROS levels are not always accompanied by changes in oxidative stress levels or antioxidant mechanisms $(46,47)$. Moreover, the increase in the GSH levels was not linear; rather, the increase in the GSH levels peaked at $400 \mu \mathrm{g} / \mathrm{ml}$ and subsequently declined, and no increase at $1,600 \mu \mathrm{g} / \mathrm{ml}$ was noted, compared with the control. The observed decline in the GSH levels may be explained by the pro-oxidant activity of coffee extracts after reaching a certain concentration, as has been observed in relation to other plant polyphenolic extracts (48-51). Indeed, 1,600 $\mu \mathrm{g} / \mathrm{ml}$ was a crucial concentration, since it was the highest concentration used which did not exert cytotoxic effects (Fig. 7). Thus, our results suggest that the tested coffee extract improved the cellular redox status by increasing the levels of GSH, one of the most important antioxidant molecules. Importantly, it has been previously reported that coffee extracts lead to protein localization of the nuclear factor (erythroid-derived 2)-like 2 (Nrf2) protein, a key transcription factor which is associated with antioxidant systems in HT-29 cells $(52,53)$. Interestingly, one of the enzymes whose expression is regulated by Nrf2 is gamma-glutamylcysteine synthetase, the first enzyme in the biosynthetic pathway of GSH (54). However, when tested in humans, considerable inter-individual differences were observed in Nrf2 localization, suggesting that the effect of coffee extracts is genotype-dependent $(55,56)$. However, as each coffee variety has a different chemical composition and thus performs a different activity, determining the potential of the coffee extracts used in our study to induce Nrf2 activity will be an intriguing task.

In conclusion, the findings of the present study indicated that coffee extracts from green or roasted beans exhibited potent free radical scavenging activity and also served to protect against the DNA damage induced by free radicals. Moreover, we noted differences in the levels of antioxidant activity between green and roasted bean extracts derived from the same variety. In some coffee varieties, bean roasting reduced antioxidant activity, whereas in others the opposite was noted. It appears that the final effect depends on the chemical composition of the beans of each coffee variety, but this hypothesis requires further investigation. In addition, roasting time was shown to affect the antioxidant activity of roasted coffee beans. This observation suggests that the roasting time should be optimized in order to maintain the levels of antioxidant activity as high as possible. Finally, the coffee extract with the highest antioxidant activity (variety 13) was also shown to enhance the antioxidant mechanisms in myoblast cells by increasing GSH levels. Currently under way is a study in which cells treated with this extract are used in DNA microarray analysis, and this is being undertaken in order to examine its effects on whole genome expression, and thus investigate in depth the molecular mechanisms responsible for its antioxidant activity. Understanding the mechanisms through which coffee acts as an antioxidant will lead to improvements in the extraction and roasting processes and the ability to fully exploit its properties.

\section{Akcnolwedgements}

The present study was funded by a grant (no. 5042; 'Assessment of antioxidant and anticarcinogenic activity of green and roasted coffee varieties') awarded to Professor D. Kouretas.

\section{References}

1. Schieber M and Chandel NS: ROS function in redox signaling and oxidative stress. Curr Biol 24: R453-R462, 2014.

2. Ray PD, Huang BW and Tsuji Y: Reactive oxygen species (ROS) homeostasis and redox regulation in cellular signaling. Cell Signal 24: 981-990, 2012.

3. Simon HU, Haj-Yehia A and Levi-Schaffer F: Role of reactive oxygen species (ROS) in apoptosis induction. Apoptosis 5: 415-418, 2000.

4. Halliwell B: Free Radicals and Other Reactive Species in Disease. In: eLS. John Wiley \& Sons, Ltd., 2001.

5. Elias RJ, Kellerby SS and Decker EA: Antioxidant activity of proteins and peptides. Crit Rev Food Sci Nutr 48: 430-441, 2008.

6. Valko M, Leibfritz D, Moncol J, Cronin MTD, Mazur M and Telser J: Free radicals and antioxidants in normal physiological functions and human disease. Int J Biochem Cell Biol 39: 44-84, 2007.

7. Birben E, Sahiner UM, Sackesen C, Erzurum S and Kalayci O: Oxidative stress and antioxidant defense. World Allergy Organ J 5: 9-19, 2012.

8. Elnakish MT, Hassanain HH, Janssen PM, Angelos MG and Khan M: Emerging role of ox idative stress in metabolic syndrome and cardiovascular diseases: important role of Rac/NADPH oxidase. J Pathol 231: 290-300, 2013.

9. Wruck CJ, Fragoulis A, Gurzynski A, Brandenburg LO, Kan YW, Chan K, Hassenpflug J, Freitag-Wolf S, Varoga D, Lippross S and Pufe T: Role of oxidative stress in rheumatoid arthritis: insights from the Nrf2-knockout mice. Ann Rheum Dis 70: 844-850, 2011.

10. Sosa V, Moliné T, Somoza R, Paciucci R, Kondoh H and LLeonart ME: Oxidative stress and cancer: an overview. Ageing Res Rev 12: 376-390, 2013.

11. Rochette L, Zeller M, Cottin Y and Vergely C: Diabetes, oxidative stress and therapeutic strategies. Biochim Biophys Acta 1840: 2709-2729, 2014.

12. Wang X, Wang W, Li L, Perry G, Lee HG and Zhu X: Oxidative stress and mitochondrial dysfunction in Alzheimer's disease. Biochim Biophys Acta 1842: 1240-1247, 2014.

13. Landete JM: Dietary intake of natural antioxidants: vitamins and polyphenols. Crit Rev Food Sci Nutr 53: 706-721, 2013.

14. Fang YZ, Yang S and Wu G: Free radicals, antioxidants, and nutrition. Nutrition 18: 872-879, 2002.

15. Landete JM: Updated knowledge about polyphenols: functions, bioavailability, metabolism, and health. Crit Rev Food Sci Nutr 52: 936-948, 2012.

16. Quideau S, Deffieux D, Douat-Casassus C and Pouysegu L: Plant polyphenols: chemical properties, biological activities, and synthesis. Angew Chem Int Ed Engl 50: 586-621, 2011.

17. Pandey KB and Rizvi SI: Plant polyphenols as dietary antioxidants in human health and disease. Oxid Med Cell Longev 2: 270-278, 2009.

18. Higdon JV and Frei B: Coffee and health: a review of recent human research. Crit Rev Food Sci Nutr 46: 101-123, 2006. 
19. Henry-Vitrac C, Ibarra A, Roller M, Mérillon JM and Vitrac X: Contribution of chlorogenic acids to the inhibition of human hepatic glucose-6-phosphatase activity in vitro by Svetol, a standardized decaffeinated green coffee extract. J Agric Food Chem 58: 4141-4144, 2010.

20. Murthy PS and Naidu MM: Recovery of phenolic antioxidants and functional compounds from coffee industry by-products. Food Bioprocess Technol 5: 897-903, 2012.

21. Park JB: Isolation and quantification of major chlorogenic acids in three major instant coffee brands and their potential effects on $\mathrm{H}_{2} \mathrm{O}_{2}$-induced mitochondrial membrane depolarization and apoptosis in PC-12 cells. Food Funct 4: 1632-1638, 2013.

22. Sato Y, Itagaki S, Kurokawa T, Ogura J, Kobayashi M, Hirano T, Sugawara M and Iseki K: In vitro and in vivo antioxidant properties of chlorogenic acid and caffeic acid. Int J Pharm 403: $136-138,2011$

23. Xu JG, Hu QP and Liu Y: Antioxidant and DNA-protective activities of chlorogenic acid isomers. J Agric Food Chem 60: 11625-11630, 2012.

24. Farah A, Monteiro M, Donangelo CM and Lafay S: Chlorogenic acids from green coffee extract are highly bioavailable in humans. J Nutr 138: 2309-2315, 2008.

25. Jaiswal R, Matei MF, Golon A, Witt M and Kuhnert N: Understanding the fate of chlorogenic acids in coffee roasting using mass spectrometry based targeted and non-targeted analytical strategies. Food Funct 3: 976-984, 2012.

26. Daglia M, Racchi M, Papetti A, Lanni C, Govoni S and Gazzani G: In vitro and ex vivo antihydroxyl radical activity of green and roasted coffee. J Agric Food Chem 52: 1700-1704, 2004.

27. Gawlik-Dziki U, Świeca M, Dziki D, Kowalska I, Pecio Ł, Durak A and Sęczyk $€$ : Lipoxygenase inhibitors and antioxidants from green coffee - mechanism of action in the light of potential bioaccessibility. Food Res Int 61: 48-55, 2014.

28. Kamiyama M, Moon JK, Jang HW and Shibamoto T: Role of degradation products of chlorogenic acid in the antioxidant activity of roasted coffee. J Agric Food Chem 63: 1996-2005, 2015.

29. Singleton VL, Orthofer R and Lamuela-Raventós RM: Analysis of total phenols and other oxidation substrates and antioxidants by means of Folin-Ciocalteu reagent. In: Methods in Enzymology, Oxidant and Antioxidants (Part A). Packer L (ed). Vol 299. Academic Press Inc., San Diego, CA, pp152-178, 1999.

30. Brand-Williams W, Cuvelier ME and Berset C: Use of a free radical method to evaluate antioxidant activity. Lwt - Food Sci Technol 28: 25-30, 1995.

31. Cano A, Hernández-Ruíz J, García-Cánovas F, Acosta M and Arnao MB: An end-point method for estimation of the total antioxidant activity in plant material. Phytochem Anal 9: 196-202, 1998.

32. Keum YS, Park KK, Lee JM, Chun KS, Park JH, Lee SK, Kwon H and Surh YJ: Antioxidant and anti-tumor promoting activities of the methanol extract of heat-processed ginseng. Cancer Lett 150 $41-48,2000$

33. Chang ST, Wu JH, Wang SY, Kang PL, Yang NS and Shyur LF: Antioxidant activity of extracts from Acacia confusa bark and heartwood. J Agric Food Chem 49: 3420-3424, 2001.

34. Rodrigues NP, Salva T de JG and Bragagnolo N: Influence of coffee genotype on bioactive compounds and the in vitro capacity to scavenge reactive oxygen and nitrogen species. J Agric Food Chem 63: 4815-4826, 2015.

35. Mills CE, Oruna-Concha MJ, Mottram DS, Gibson GR and Spencer JPE: The effect of processing on chlorogenic acid content of commercially available coffee. Food Chem 141: 3335-3340, 2013

36. Smrke S, Opitz SEW, Vovk I and Yeretzian C: How does roasting affect the antioxidants of a coffee brew? Exploring the antioxidant capacity of coffee via on-line antioxidant assays coupled with size exclusion chromatography. Food Funct 4: 1082-1092, 2013.

37. Esquivel P and Jiménez VM: Functional properties of coffee and coffee by-products. Food Res Int 46: 488-495, 2012.
38. Nicoli MC, Anese M, Manzocco L and Lerici CR: Antioxidant Properties of Coffee Brews in Relation to the Roasting Degree. LWT Lebensmittel Wissenschaft \& Technologie 30: 292-297, 1997.

39. Cämmerer B and Kroh L: Antioxidant activity of coffee brews Eur Food Res Technol 223: 469-474, 2006.

40. Perrone D, Farah A and Donangelo CM: Influence of coffee roasting on the incorporation of phenolic compounds into melanoidins and their relationship with antioxidant activity of the brew. J Agric Food Chem 60: 4265-4275, 2012.

41. Halliwell B: Reactive species and antioxidants. Redox biology is a fundamental theme of aerobic life. Plant Physiol 141: 312-322, 2006.

42. Stadler RH, Turesky RJ, Müller O, Markovic J and Leong-Morgenthaler PM: The inhibitory effects of coffee on radical-mediated oxidation and mutagenicity. Mutat Res 308: 177-190, 1994.

43. Cavin C, Holzhaeuser D, Scharf G, Constable A, Huber WW and Schilter B: Cafestol and kahweol, two coffee specific diterpenes with anticarcinogenic activity. Food Chem Toxicol 40: 1155-1163, 2002.

44. Lee KJ and Jeong HG: Protective effects of kahweol and cafestol against hydrogen peroxide-induced oxidative stress and DNA damage. Toxicol Lett 173: 80-87, 2007.

45. Apostolou A, Stagos D, Galitsiou E, Spyrou A, Haroutounian S, Portesis N, Trizoglou I, Wallace Hayes A, Tsatsakis AM and Kouretas D: Assessment of polyphenolic content, antioxidant activity, protection against ROS-induced DNA damage and anticancer activity of Vitis vinifera stem extracts. Food Chem Toxicol 61: 60-68, 2013

46. Kerasioti E, Stagos D, Priftis A, Aivazidis S, Tsatsakis AM, Hayes AW and Kouretas D: Antioxidant effects of whey protein on muscle C2C12 cells. Food Chem 155: 271-278, 2014.

47. Goutzourelas N, Stagos D, Demertzis N, Mavridou P, Karterolioti H, Georgadakis S, Kerasioti E, Aligiannis N, Skaltsounis L, Statiri A, et al: Effects of polyphenolic grape extract on the oxidative status of muscle and endothelial cells. Hum Exp Toxicol 33: 1099-1112, 2014

48. Procházková $\mathrm{D}$, Boušová I and Wilhelmová N: Antioxidant and prooxidant properties of flavonoids. Fitoterapia 82: 513-523, 2011.

49. Lambert JD and Elias RJ: The antioxidant and pro-oxidant activities of green tea polyphenols: a role in cancer prevention. Arch Biochem Biophys 501: 65-72, 2010.

50. Fukumoto LR and Mazza G: Assessing antioxidant and prooxidant activities of phenolic compounds. J Agric Food Chem 48: 3597-3604, 2000.

51. Sakihama Y, Cohen MF, Grace SC and Yamasaki H: Plant phenolic antioxidant and prooxidant activities: phenolics-induced oxidative damage mediated by metals in plants. Toxicology 177 : 67-80, 2002.

52. Boettler U, Sommerfeld K, Volz N, Pahlke G, Teller N, Somoza V, Lang R, Hofmann T and Marko D: Coffee constituents as modulators of Nrf2 nuclear translocation and ARE (EpRE)-dependent gene expression. J Nutr Biochem 22: 426-440, 2011.

53. Volz N, Boettler U, Winkler S, Teller N, Schwarz C, Bakuradze T, Eisenbrand G, Haupt L, Griffiths LR, Stiebitz H, et al: Effect of coffee combining green coffee bean constituents with typical roasting products on the Nrf2/ARE pathway in vitro and in vivo. J Agric Food Chem 60: 9631-9641, 2012.

54. Myhrstad MCW, Carlsen H, Nordström O, Blomhoff R and Moskaug JO: Flavonoids increase the intracellular glutathione level by transactivation of the gamma-glutamylcysteine synthetase catalytical subunit promoter. Free Radic Biol Med 32: 386-393, 2002

55. Boettler U, Volz N, Teller N, Haupt LM, Bakuradze T, Eisenbrand G, Bytof G, Lantz I, Griffiths LR and Marko D: Induction of antioxidative Nrf2 gene transcription by coffee in humans: depending on genotype? Mol Biol Rep 39: 7155-7162, 2012.

56. Hassmann U, Haupt LM, Smith RA, Winkler S, Bytof G, Lantz I, Griffiths LR and Marko D: Potential antioxidant response to coffee - A matter of genotype? Meta Gene 2: 525-539, 2014. 